\title{
North American Branchiobdellida (Annelida: Clitellata) or Crayfish Worms in France: the most diverse distribution of these exotic ectosymbionts in Europe
}

\author{
JEAN-FRANÇOIS PARPET ${ }^{1} \&$ STUART R. GELDER ${ }^{2, *}$ \\ ${ }^{\prime}$ Royal Belgian Institute of Natural Sciences, Operational Directorate Taxonomy and Phylogeny, Vautier Street 29, B-1000 Brussels, \\ Belgium. \\ ${ }^{2}$ University of Maine at Presque Isle, 181 Main Street, Presque Isle, Maine 04769, USA. E-Mail: stuart.gelder@maine.edu \\ *Corresponding author: stuart.gelder@maine.edu
}

\begin{abstract}
Crayfishes and other invertebrates were collected during 2010 to 2016 from 519 sites located in the river basins of the Adour, Charente, Dordogne, Garonne, Loire, Seine, Rhône and Sélune in France. North American species included Pacifastacus leniusculus at 255 sites, Faxonius limosus at 206 sites, Procambarus clarkii at 56 sites, and the endemic Austropotamobius pallipes at two sites. However, branchiobdellidans were only recorded from 100 sites with 23 of these being sampled more than once, resulting in a total of 127 collections.

The widely distributed western North American, P. leniusculus carried four of its endemic branchiobdellidan species: Cambarincola gracilis, C. okadai, Triannulata magna and Xironogiton victoriensis. X. victoriensis was found at the majority of sites, with C. okadai, C. gracilis, and T. magna at fewer locations. Although F. limosus was the second most numerous crayfish species collected, it did not carry any of its endemic North American branchiobdellidan species. However, it was found cohabiting with P. leniusculus at four sites but carried $X$. victoriensis at only one of these. European A. pallipes only occurred at two sites with individuals harboring $X$. victoriensis, although no cohabiting exotic crayfish were found. Crayfish were also absent from three sites where free-living $X$. victoriensis were recovered from substrate samples. Procambarus clarkii appeared at sites scattered across the country, while specimens with $C$. mesochoreus were restricted to the Adour drainage.

This study has shown the widespread distribution of exotic branchiobdellidans in the wild and the virtual extinction of endemic species in France. In addition, we have provided the first European record of T. magna, and the first record of $C$. mesochoreus in France; the latter being only the second recording in Europe. With this comprehensive survey of their crayfish hosts in France, monitoring future exotic range expansions and endemic contraction or extinction can be traced. These data will be available to authorities for future planning in maintaining healthy freshwater bodies by reducing the damaging effects caused by exotic crayfishes.
\end{abstract}

Keywords: Ectosymbiosis, French distribution, Triannulata magna, Cambarincola mesochoreus, Cambarincola gracilis, Cambarincola okadai, Xironogiton victoriensis, North American crayfish, Pacifastacus leniusculus, Procambarus clarkii, Faxonius limosus, Austropotamobius pallipes

\section{Introduction}

The French naturalist, Alphonse Odier, discovered specimens of Branchiobdella astaci Odier, on Astacus astacus (Linnaeus) in 1819 and this became the second species to be described in the Branchiobdellida (Annelida: Clitellata) or crayfish worms. Unfortunately reports of this and subsequent finds of $B$. astaci, Branchiobdella hexadonta Gruber, Branchiobdella parasita (Braun) and Branchiobdella pentadonta Whitman in the country were not accompanied by any detailed collection site information (Odier 1823; 
Subchev $2014 \& 2016$ ). As a result, French distribution records on branchiobdellidans are very limited, consisting only of Austropotamobius pallipes (Lereboullet) carrying B. astaci at Grand Lac Laffrey, south of Grenoble, from the Druyes river, a tributary of the Yonne river, southeast of Paris (Subchev 2008), A. pallipes carrying $B$. hexadonta from an unidentified stream in an unlocated locality called "La Roche" (Subchev 2008), A. pallipes supporting B. astaci and B. pentadonta from an unidentified stream at Saint-Quentin-surCoole, Marne Department (Subchev 2016), an unknown crayfish host supporting B. pentadonta in an unknown stream at Strasbourg, Bas-Rhin Department (Subchev 2008) and finally with A. astacus supporting B. astaci in ponds at Thonnance-les-Joinvilles, Haute-Marne Department (J.-F. Parpet, unpub. data). Interest increased when exotic, North American branchiobdellidans were found on their translocated crayfish hosts. The first record in France of Pacifastacus leniusculus (Dana) carrying Xironogiton victoriensis Gelder and Hall, came from the River Lot, when a fisherman brought specimens to Laurent (2007) for identification; no details of location, date etc. were reported. Similarly, Subchev (2008) found the same association on a specimen from the River Dourbie, a tributary of the Tarn River, in the crayfish collection of the French National Museum of Natural History (Paris); again, collection details had not been recorded. However, collections of P. leniusculus from 11 recorded sites in the Rivers Lot, Tarn and Mayenne, recovered three branchiobdellidan species: Cambarincola gracilis Robinson, Cambarincola okadai Yamaguchi, and $X$. victoriensis (Gelder et al. 2012). Subsequently, Lecaplain and Noël (2015) reported P. leniusculus with the same three branchiobdellidans in Northwest France, probably from the Mayenne and Sélune River drainages. Following publication, they realized the report of $C$. gracilis in this region was an error (B. Lecaplain, pers. comm.). These imported crayfish were destined for human consumption, and the presence of branchiobdellidans mistakenly identified as parasitic leeches by consumers, reduced the public's interest for their hosts (J.-F. Parpet, unpub. obs.). In reality, most branchiobdellidans feed on epibiota attached to the crayfish's exoskeleton so they actually perform a beneficial host cleaning function thus forming a mutualistic association. However, the branchiobdellidan/ host relationship can vary, with periods of mutualism, commensalism or parasitism, depending on the species and habitat conditions (Skelton et al. 2013; Ames et al. 2015).

The three most important commercial North American crayfishes translocated to Europe are: $P$. leniusculus, Procambarus clarkii (Girard) and Faxonius limosus (Rafinesque), and all of them have been reported in France (Holdich et al. 2009; Kouba et al. 2015). Details of P. leniusculus translocations from the USA's northwestern states and subsequent multiple stockings in Europe, France in particular, were presented in Gelder et al. (2012). The European distribution of P. clarkii favors southwestern Europe which includes south and southwest France, while F. limosus extends from France in a wide band to Poland (Kouba et al. 2015). Recently these crayfishes were joined in northeastern France by Faxonius juvenilis (Hagen) in 2005, and Faxonius immunis (Hagen) in 2010 (Kouba et al. 2014), however, no branchiobdellidans have been reported on these new arrivals. Gelder (2004) listed the endemic branchiobdellidan species that were known on the three major commercial North American crayfishes and predicted their likely appearance in the importing countries. Currently four of these North American branchiobdellidan species have been recorded in Europe. The first one to be reported was X. victoriensis ( $=$ X. instabilis under various spellings) in Sweden by Franzén (1962), and subsequently in Finland (Kirjavainen \& Westman 1999), Austria (Nesemann \& Neubert 1999), Spain (Gelder 1999), Italy (Quaglio et al. 2002), Germany (Martens et al. 2006), Hungary (Kovács \& Juhász 2007), France (Laurent 2007), Wales (James et al. 2015), Croatia (Dražina et al. 2018), Luxembourg (Dr. D. Templeman, pers. comm.) and Switzerland (R. Krieg, pers. comm.). This species has since been joined by $C$. gracilis, and C. okadai, in France (Gelder et al. 2012), with the latter species also appearing in Wales (James et al. 2015). Although P. clarkii is widespread in southwestern Europe, it is surprising there has been only one report of it carrying an endemic branchiobdellidan, and that was Cambarincola mesochoreus Hoffman, in northern Italy (Gelder et al. 1994). Continued translocations and natural range expansions are introducing these exotic crayfishes, and in some cases their branchiobdellidans, into new European freshwater habitats.

The present study in France was designed to extend the preliminary survey reported in Gelder et al. (2012) by sampling new sites and resampling previous sites at different times of year. These data will provide a detailed National baseline for local and state authorities to address the negative impact of exotic species on their freshwater habitats. Fortunately, these dangers to France's endemic freshwater fauna have already been recognized resulting in many state and local authorities increasing their monitoring programs as a prelude to future conservation legislation. 


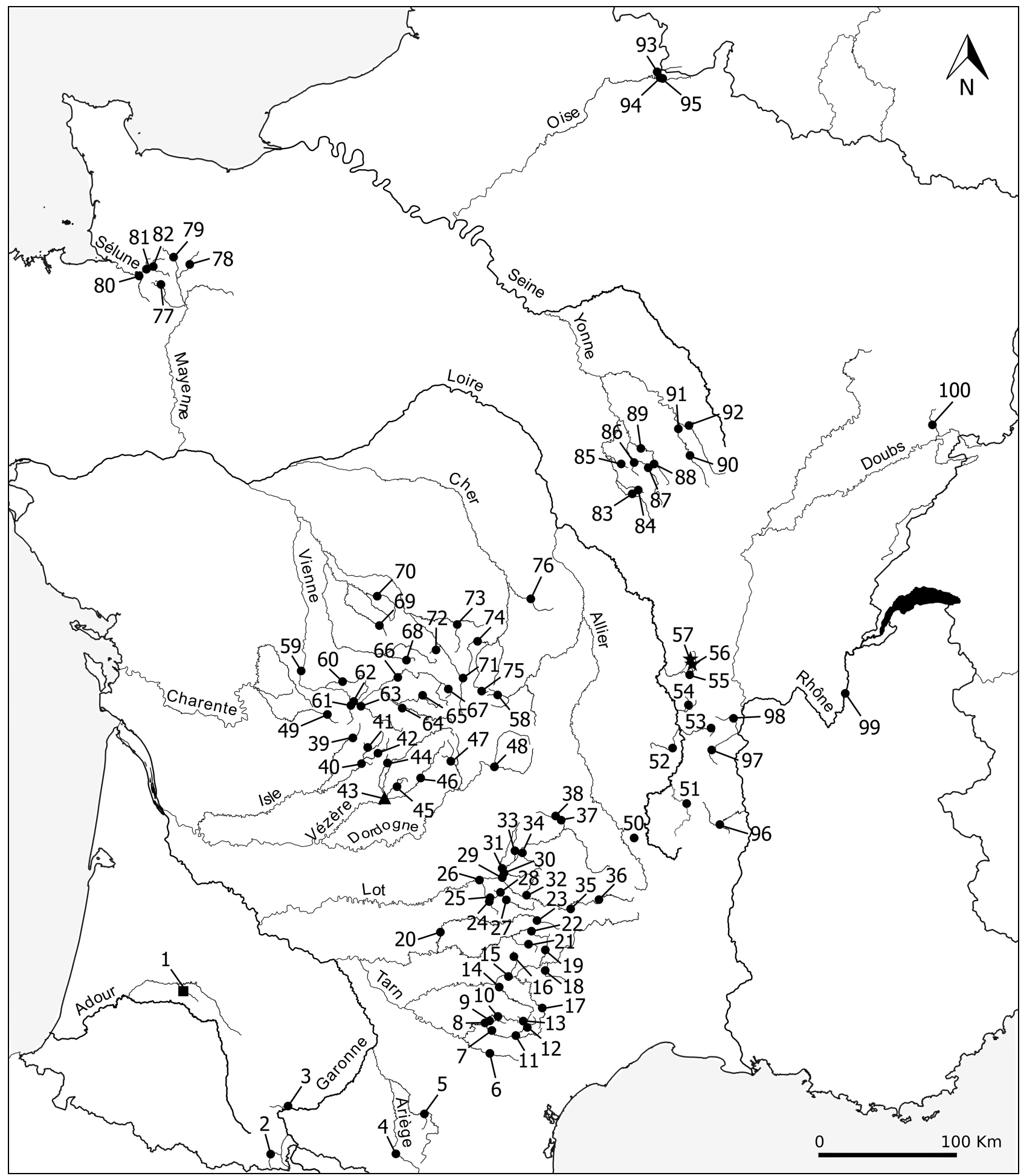

FIGURE 1. Map of France showing numbered sites where branchiobdellidans were collected, while the other crayfish sites have been omitted for clarity: discs, Pacifastacus leniusculus; square, Procambarus clarkii; triangle, Faxonius limosus and stars, Austropotamobius pallipes.

\section{Material and methods}

Five hundred and nineteen collection sites across France were located in the river basins of the Seine (Oise and Yonne drainages), Loire (Rhins, Allier, Cher, Vienne and Mayenne drainages), Dordogne (Isle and Vézère drainages), Garonne (Lot, Tarn and Ariège drainages), Rhône (Doubs) as well as the Sélune, Charente and 
Adour basins (Table 1 and Fig. 1). Collections of crayfishes and their branchiobdellidan ectosymbionts were usually made along with other invertebrates as part of surface-water quality monitoring for French Water Agencies Adour-Garonne, Loire-Bretagne and Seine-Normandie during 2010-2016. Crayfishes were also captured during fish population monitoring in rivers for the Office National de l'Eau et des Milieux Aquatiques (ONEMA, today AFB, Agence Française pour la Biodiversité) in 2013-2016 (data access: http:// www.naiades.eaufrance.fr/acces-donnees\#/hydrobiologie). The majority of these collections were conducted during contract work by Asconit Consultants, Lyon, France, with additional collections being made by sport fishing enthusiasts. Specimens of the endemic A. pallipes were caught alive in the Drioule and Mardoret rivers (Rhône Department) during the springs of 2014 and 2016 as part of the fish and crayfish monitoring program of the Rhin's drainage (Loire basin) by the Fédération Départementale du Rhône et de la Métropole de Lyon pour la Pêche et la Protection du Milieu Aquatique, La Tour-de-Salvagny, France.

Exotic crayfishes, P. leniusculus, P. clarkii and F. limosus, were captured using one of four methods. Usually a Surber macro invertebrate stream net ("S" in Table 1) was used following the protocol described in Gelder et al. (2012), then captured crayfish were preserved in a 10\% formalin solution for examination. Crayfishes immobilized by an electro-fishing protocol ("E" in Table 1) were transferred to holding tanks with dip nets. A collapsible Lift net or Balance method (Kozák et al. 2015) was used in streams with large crayfish populations ("B" in Table 1). A benthic nylon gill net ("G" in Table 1) was set between 1.7 and $2 \mathrm{~m}$ deep for about 12 hs overnight in Lake Bouchet, a crater lake at $1200 \mathrm{~m}$ altitude (site 55, Table 1 and Fig. 1), and on retrieving the net, crayfish were found eating any trapped fish. Crayfish caught by electro-fishing, balance and gill net, were preserved in 70\% ethanol. Specimens of A. pallipes are protected and were hand collected ("H" in Table 1) alive at night with flashlights, marked and their body dimensions measured. Only their exposed surface was examined and any branchiobdellidans observed were removed before the crayfish were carefully returned to the river, thus preventing any bodily damage and minimizing handling stress.

In the laboratory all exotic crayfishes were identified, and their exposed surface and branchial chambers examined for branchiobdellidans; the worms found were transferred into $70 \%$ ethanol-containing tubes. Branchiobdellidans from each collection site were separated into groups based on body shape and size, and up to ten specimens were selected from each group. These were then dehydrated in a graded ethanol series from $70 \%$ to $99 \%$, cleared in oil of wintergreen, infiltrated with Canada balsam, and mounted individually on a microscope slide under a cover-glass (Gelder \& Williams 2015). Specimens were examined using an Olympus BX53F with Differential Interference Contrast (DIC) illumination and photographed with a Nikon 5100 camera mounted adapter lens \#6144 providing 2.5X and 4X additional magnification. Unmounted branchiobdellidans were photographed using a Leica IC80 HD digital camera mounted on a Leica MZ95 zoom stereomicroscope with Leica CLS 150 X cold light source illumination. Morphological terminology used in the brief descriptions follows that in Gelder and Williams (2015). The results obtained were largely qualitative and therefore unsuitable for the statistical analyses usually applied to studies of branchiobdellidancrayfish associations.

\section{Results}

Crayfishes were collected from a total of 519 sites with the exotic Pacifastacus leniusculus being present at 255 sites, Faxonius limosus at 206 sites, Procambarus clarkii at 56 sites, and the endemic Austropotamobius pallipes at two sites. However, branchiobdellidans were only recorded from 100 sites (Table 1) and consisted of five North American species: Cambarincola gracilis, C. mesochoreus, C. okadai, Triannulata magna Goodnight, and X. victoriensis. Although collections were made at 100 numbered sites (Fig. 1), 23 of which were visited twice on different dates and two received three visits (Table 1), resulting in 127 collections. The multiple site visits provided an indication of the stability of species incidence.

Infected P. leniusculus were found in upland, cool waters mainly in the north facing Pyrénées, Massif Central, Plateau de Millevaches, Massifs Morvan and Jura, with an isolated group in southwestern Normandie and another near Saint-Michel, Aisne Department in northeast France (Fig. 1). These crayfish carried $X$. victoriensis at 95 sites, either as the only species at 58 sites or part of a cohabiting group at 37 others. Where $X$. victoriensis was the only species, 10 sites received more than one visit, usually separated by a year. These data establish $X$. victoriensis as the most widespread branchiobdellidan species in France with an abundance ranging from one, e.g., at site 15, to 784 individuals at site 97 . 


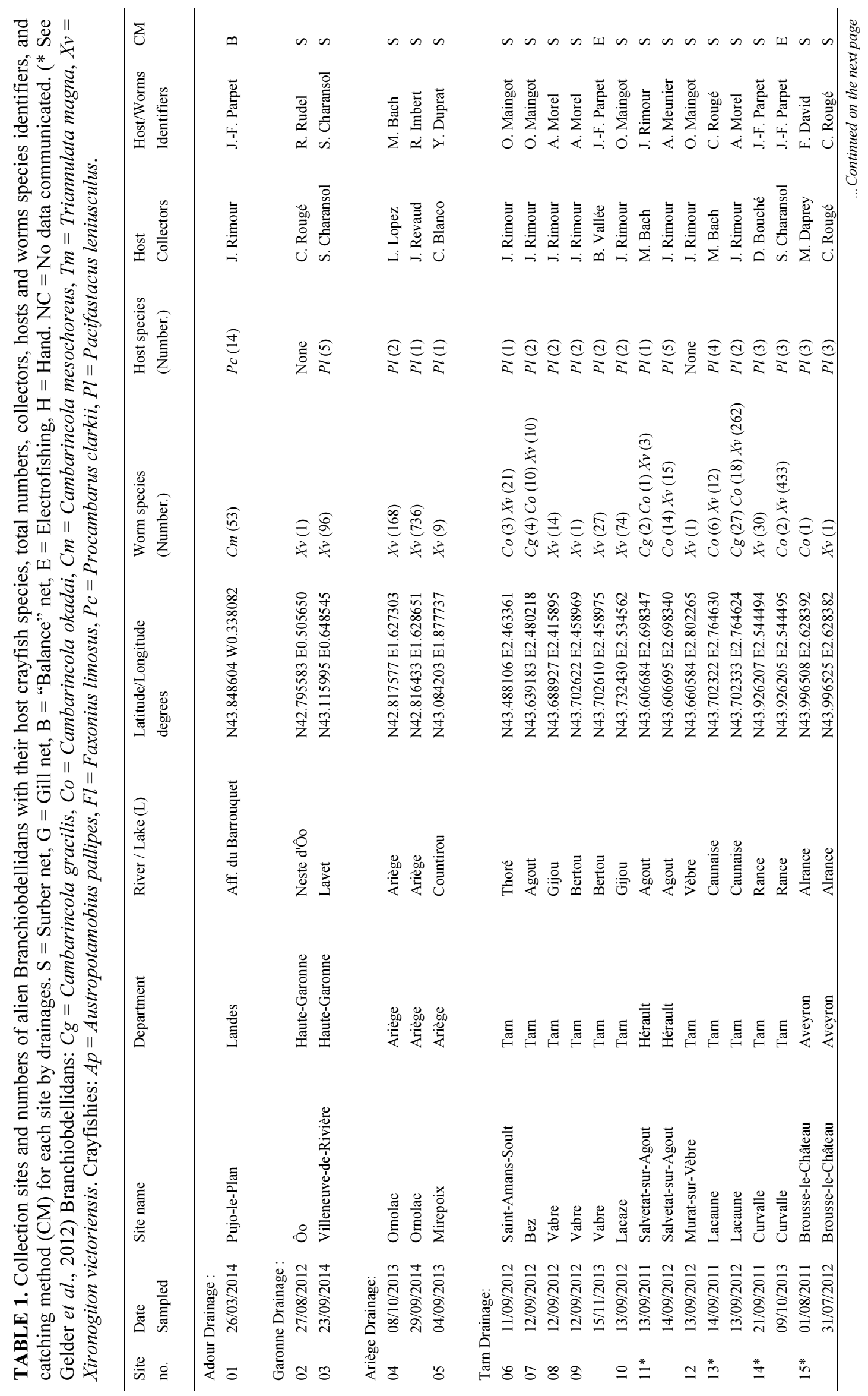




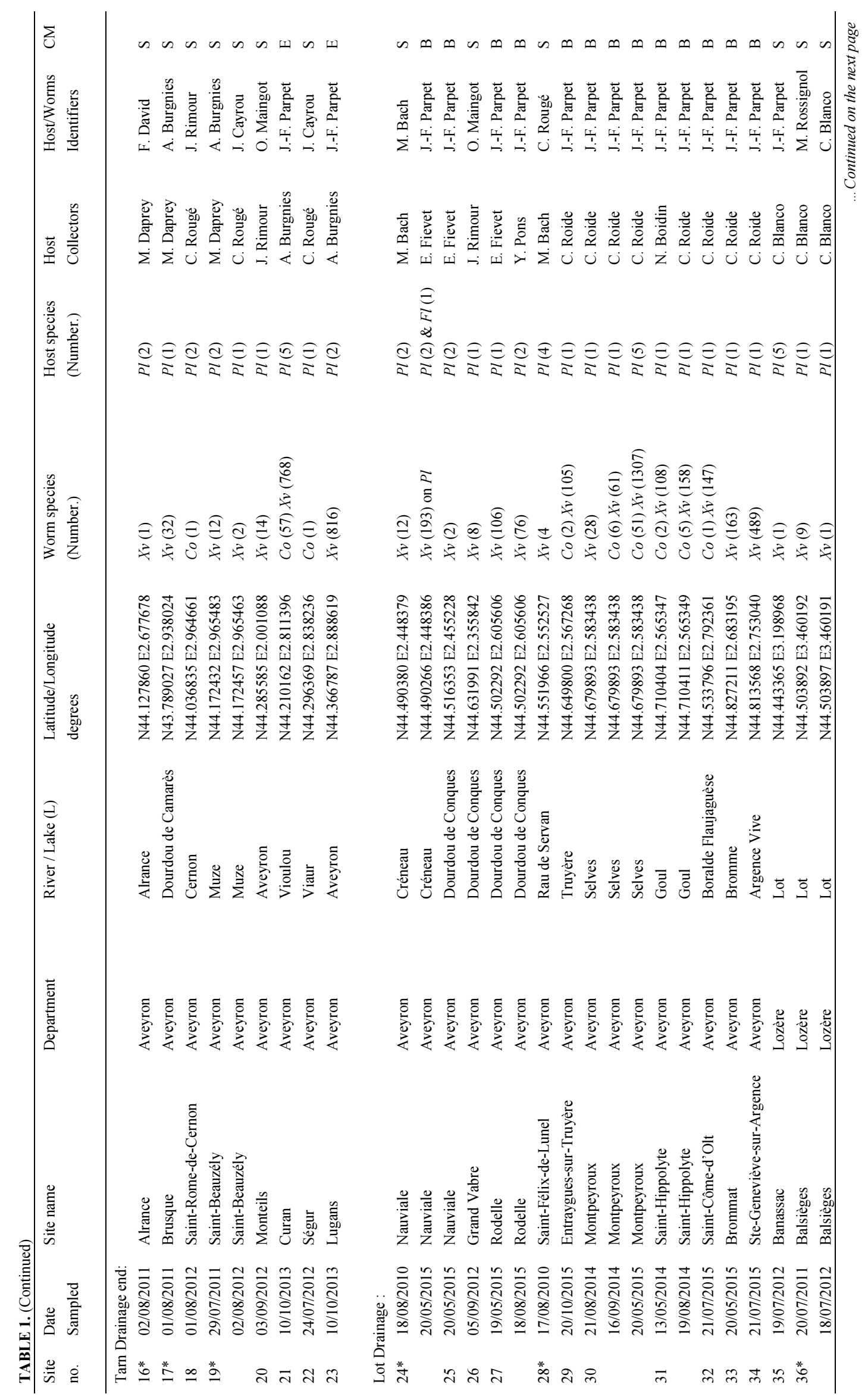




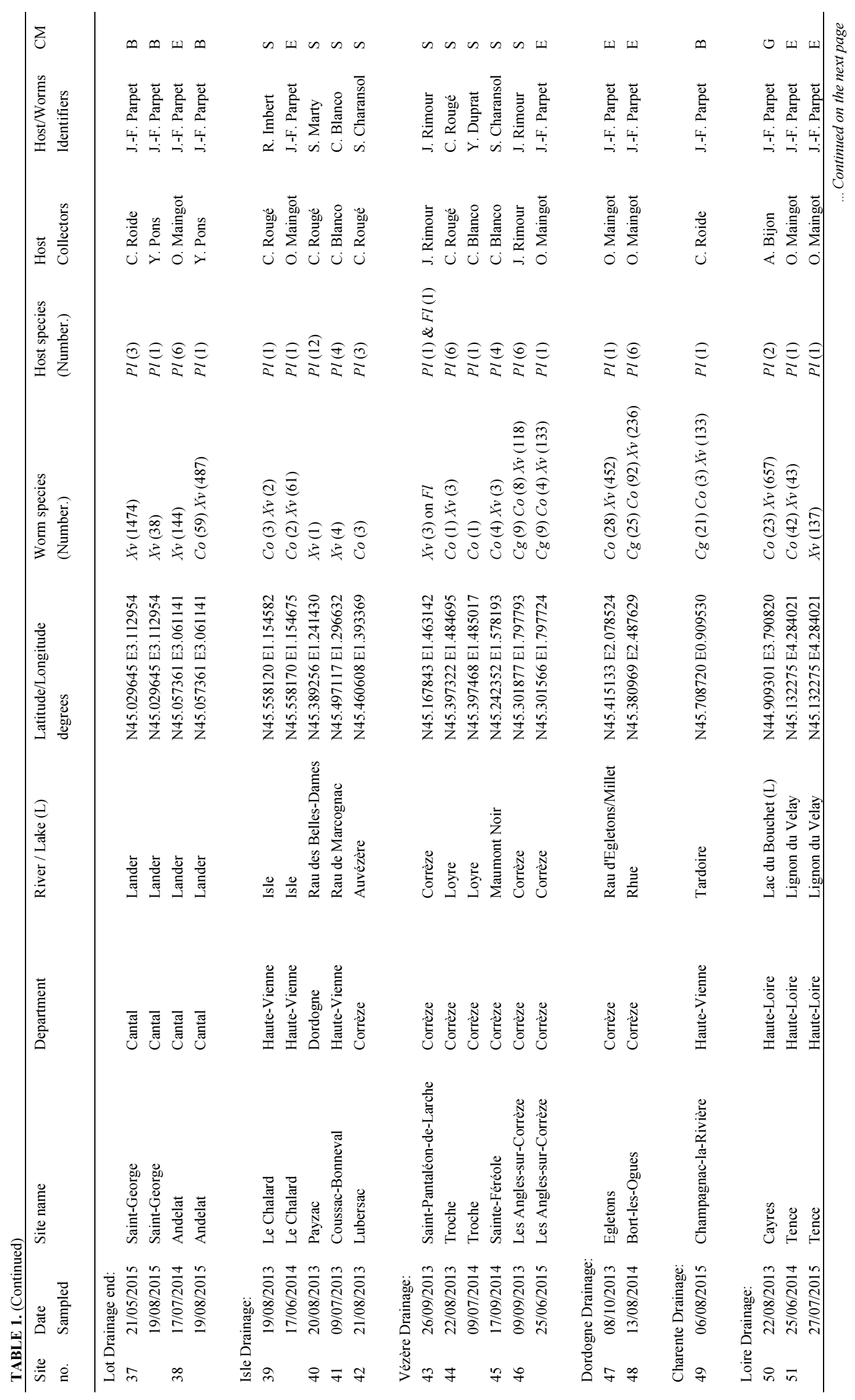




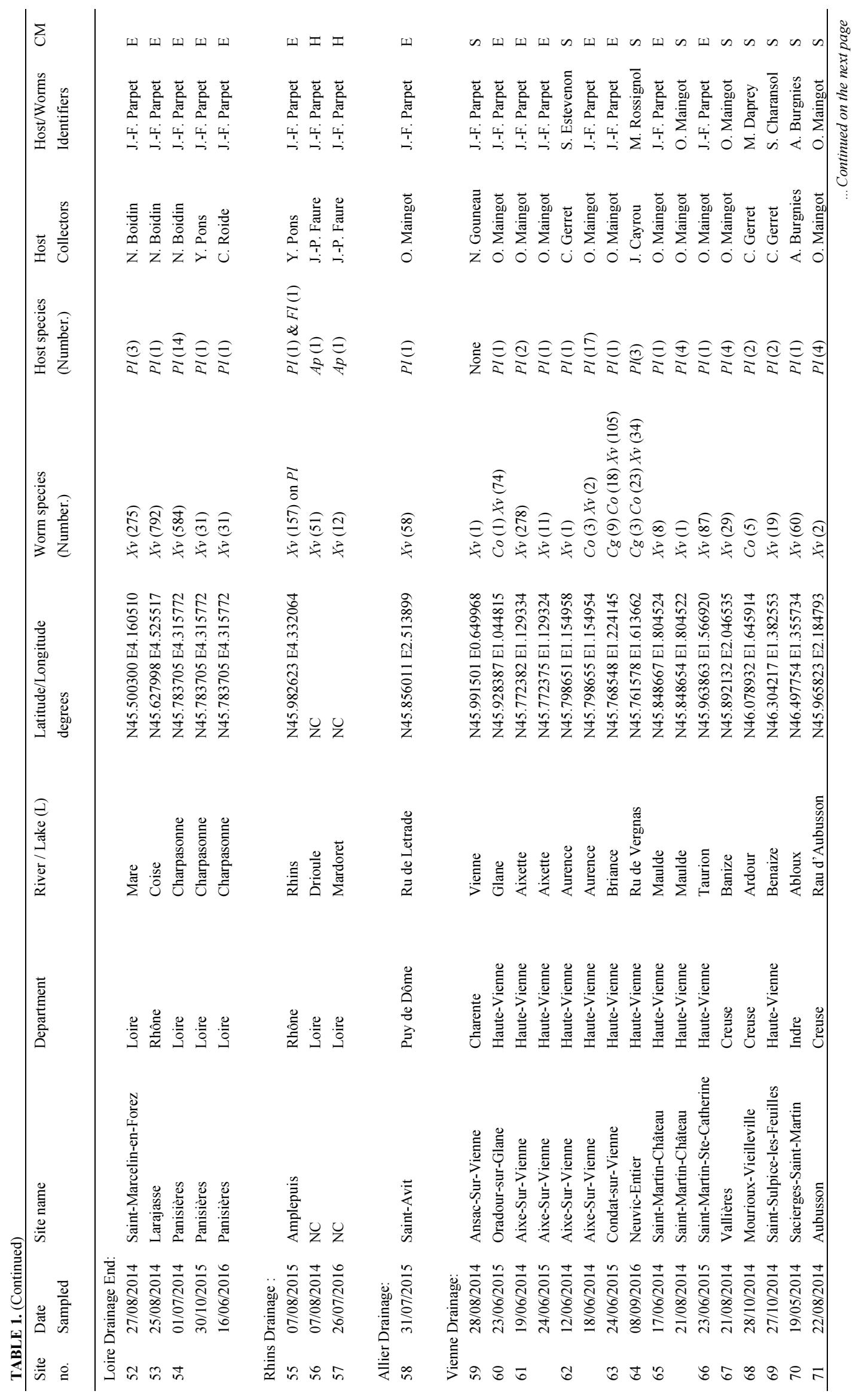




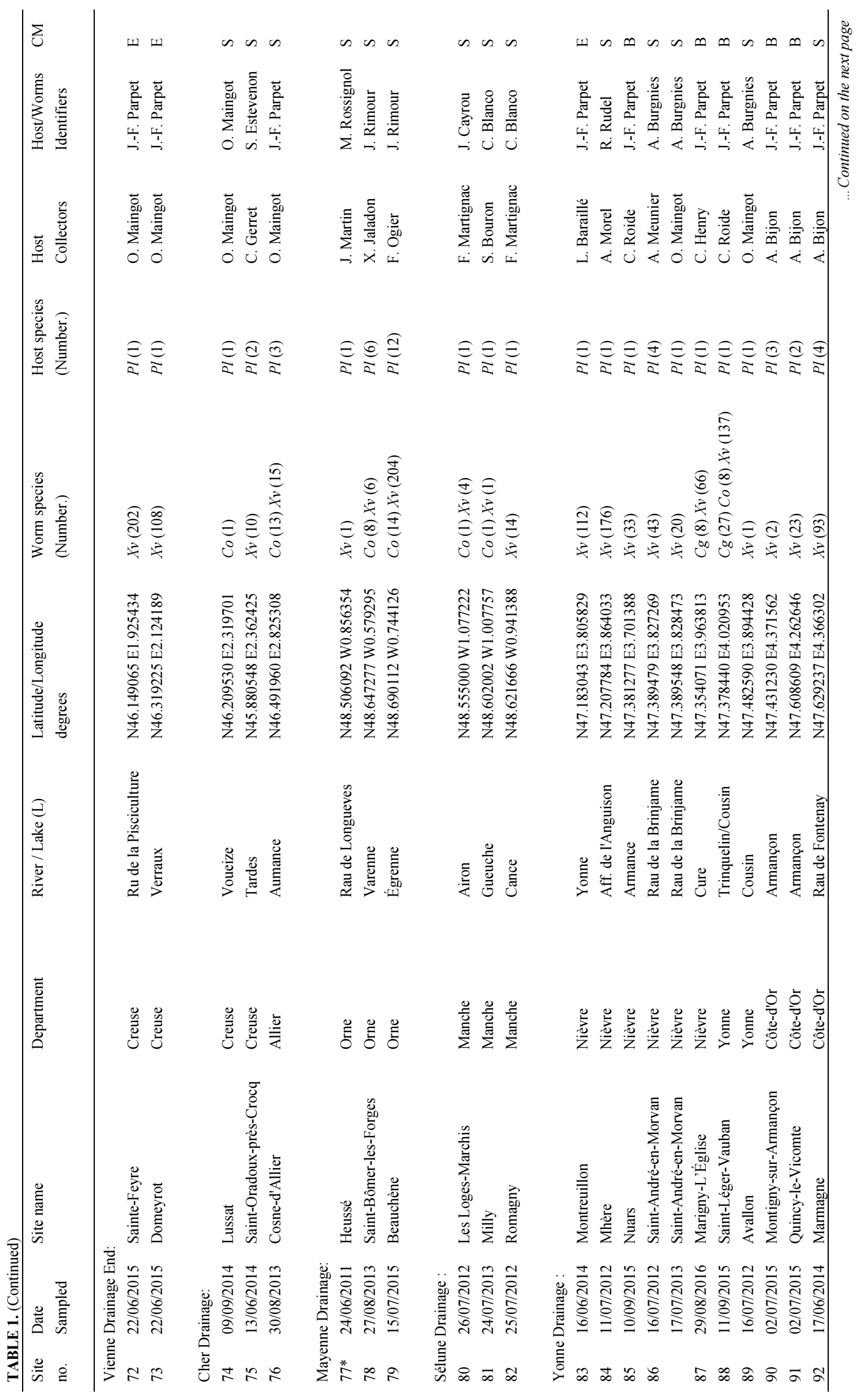




\begin{tabular}{|c|c|c|c|c|}
\hline$\sum$ & $n \backsim \infty n$ & $n$ & の山ш & $\infty$ \\
\hline 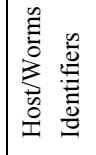 & 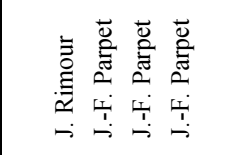 & 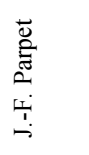 & 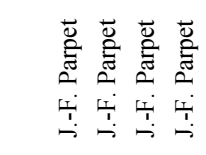 & 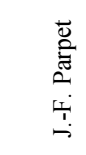 \\
\hline 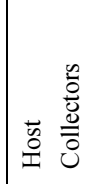 & 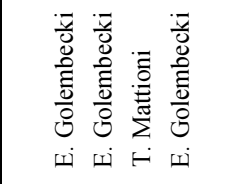 & 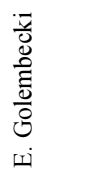 & 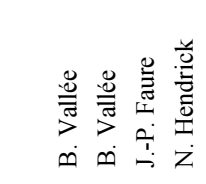 & $\begin{array}{l}\frac{0}{0} \\
\propto 2 \\
0\end{array}$ \\
\hline 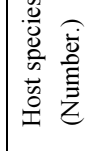 & 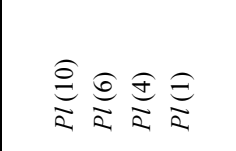 & $\underset{\Xi}{\Xi}$ & 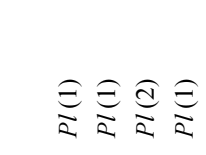 & $\stackrel{\sqrt{2}}{\stackrel{\infty}{\Xi}}$ \\
\hline 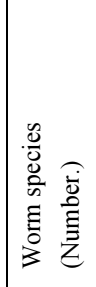 & 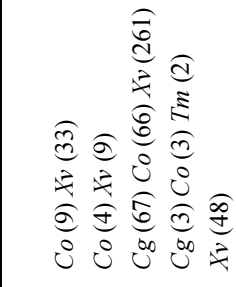 & 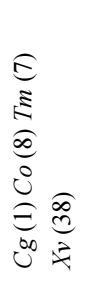 & 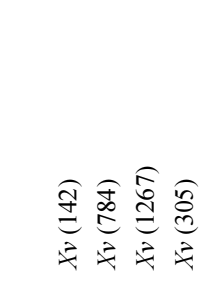 & 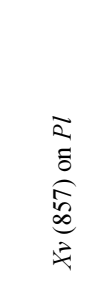 \\
\hline 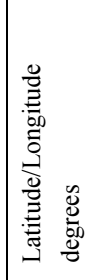 & 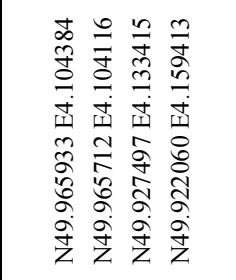 & 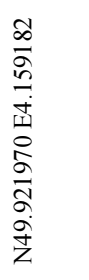 & 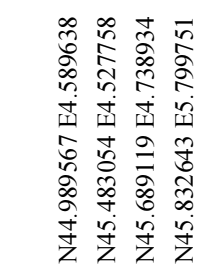 & 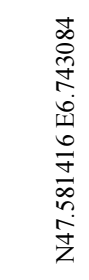 \\
\hline 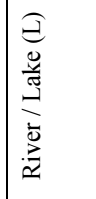 & 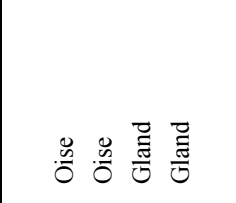 & $\begin{array}{l}\text { 픈 } \\
\text { 造 }\end{array}$ & 总 & 总 \\
\hline 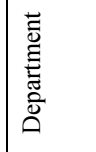 & 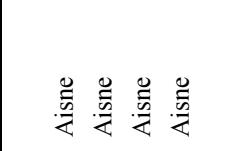 & 总 & 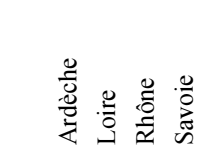 & 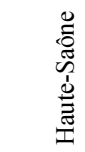 \\
\hline 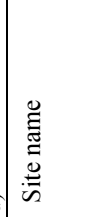 & 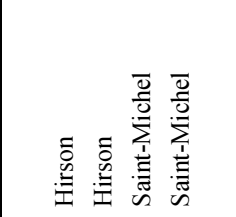 & 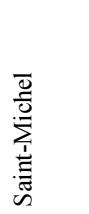 & 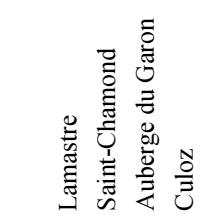 & 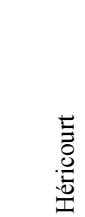 \\
\hline 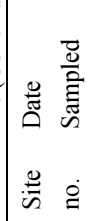 & 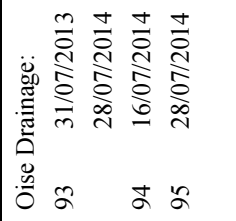 & 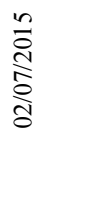 & 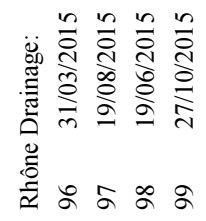 & 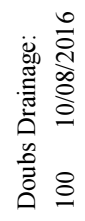 \\
\hline
\end{tabular}


Although C. okadai was the sole species on P. leniusculus at sites $18,22,68$ and 74 , it was more usual to find it cohabiting along with $X$. victoriensis as reported at sites $45,47,50,60,76,78,79,80,81$ and 87 . In addition, two collections about a year apart were made at sites 31,32, 39 and 93, indicating the stability of the cohabitating populations. In contrast, only $C$. okadai was recorded at site 15 in 2011, followed by only $X$. victoriensis in 2012. While at other site examinations separated by about a year, X. victoriensis was found initially and then both $C$. okadai and $X$. victoriensis at sites 30, 38 and 62, with the reverse occurring at sites 44 and 51 with $C$. okadai initially then $C$. okadai and X. victoriensis. A triple species cohabitation of $C$. gracilis, $C$. okadai, and $X$. victoriensis was identified at eight sites (7, 46, 48, 49, 63, 64, 88 and 94), while one of the double collections at sites 11 and 13, lacked C. gracilis. Site 95 near Saint-Michel in northeast France was unique in that two collections, one in 2014 and the other in 2015, both captured a single crayfish each time carrying four species, C. gracilis, C. okadai, T. magna and $X$. victoriensis.

Although site 43 was cohabited by $P$. leniusculus and $F$. limosus, $X$. victoriensis was only present on the latter host with adult worms occupying their usual position on the chelae and cocoons on the protected inner surface (Figs 2 and 3). A more unexpected adoption was found at sites 56 and 57 where the North American $X$. victoriensis had populated the European indigenous white-clawed crayfish, A. pallipes. In addition to monitoring invertebrates, which included crayfishes, samples of substrate were also collected from many sites for mesofaunal examination. Although no crayfish were captured from sites 2, 12 and 59, specimens of $X$. victoriensis were recovered from the substrate collections. Procambarus clarkii was only found at site 1 in the central Adour basin, southwest France (Fig. 1, Table 1) where it carried Cambarincola mesochoreus, making this the first record of $C$. mesochoreus in France.

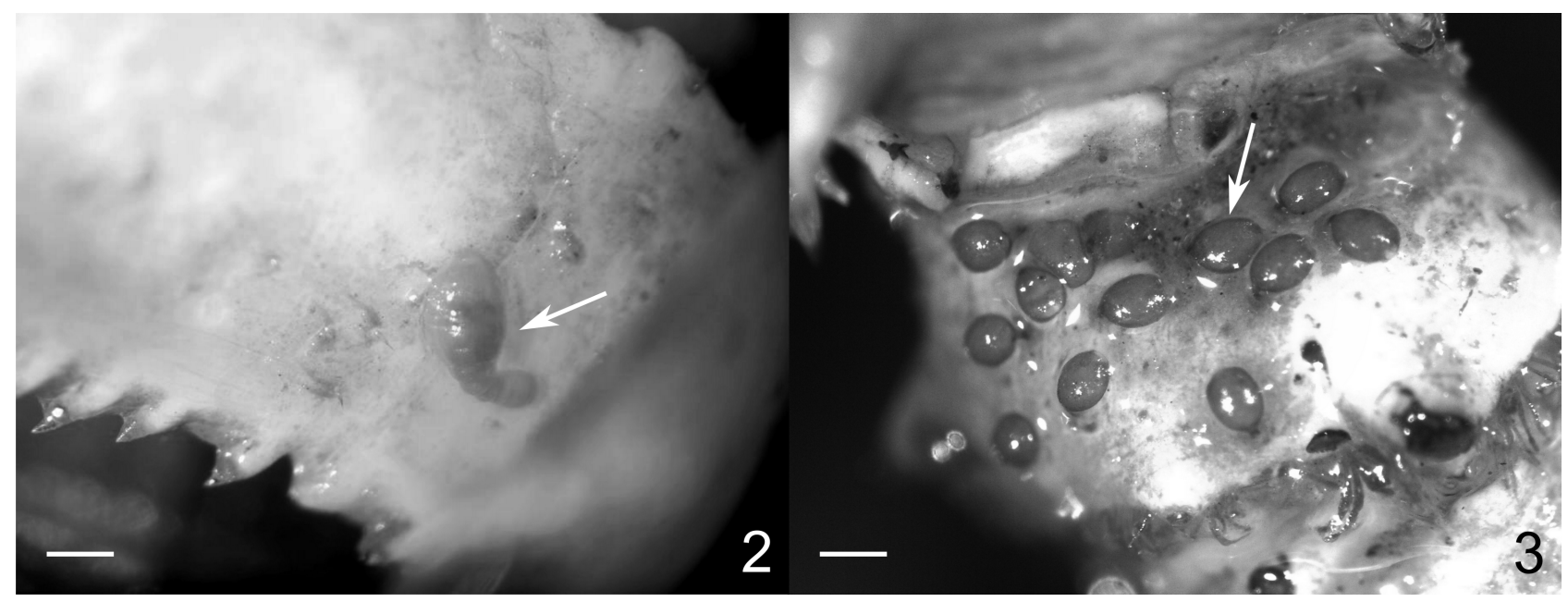

FIGURES 2-3. Xironogiton victoriensis. Fig. 2. Adult in dorsal aspect on the external surface of Faxonius limosus cheliped's merus, bar $=1 \mathrm{~mm}$. Fig. 3. Cocoons on F. limosus internal surface of cheliped's carpus, bar $=40 \mu \mathrm{m}$.

Brief descriptions and observations of the two newly reported exotic North American branchiobdellidan species

Previously Gelder et al. (2012) provided diagnostic descriptions for C. gracilis and C. okadai reported in France, and so similar information are presented here for T. magna and C. mesochoreus. As juvenile worms lack male organs, they can only be tentatively identified by their jaws when collected along with adult specimens; cocoons are similarly recognized by association and inference. Reference specimens of the five exotic North American branchiobdellidan species collected in France were submitted to Professor Jean-Loup Justine, Curator of the Annelida Collection at the Museum National d'Histoires Naturelles (MNHN), Paris, France, on April $25^{\text {th }}, 2017$. The museum's registration number of a specimen is followed in parentheses by its site number taken from Table 1: Cambarincola gracilis, HEL647 (site 11), HEL651 (site 7) and HEL652 (site 95); C. mesochoreus, HEL655 (site 1); C. okadai, HEL648 (site 11), HEL653 (site 7) and HEL654 (site 95); Triannulata magna, HEL649 (site 95) and HEL656 (site 95) and Xironogiton victoriensis, HEL650 (site 36) and HEL657 (site 95).

Triannulata magna Goodnight, 1940: Adults have a large triangular head and elongated ovoid body, 
measuring 3.5 to $5.5 \mathrm{~mm}$ long, with three annuli per segment and no transverse segmental ridges (Figs 4 and 6). The dorsal peristomial lip is without lobes and the jaws have a dental formula of 8-1-8/8-1-8 (Figs 6 and 8). Both dorsal and ventral jaws are triangular with a large median tooth and eight pairs of very small lateral teeth (Fig. 8), however, the lateral teeth may not be visible resulting in an apparent dental formula of 1/1. Spermatozoa occur in segments 5 and 6, while the male organs consist of a sac-shaped glandular atrium (ga), a muscular atrium of similar length and spherical bursa containing an eversible penis in segment 6 (Figs 6 and 7) (emended from Holt 1974).
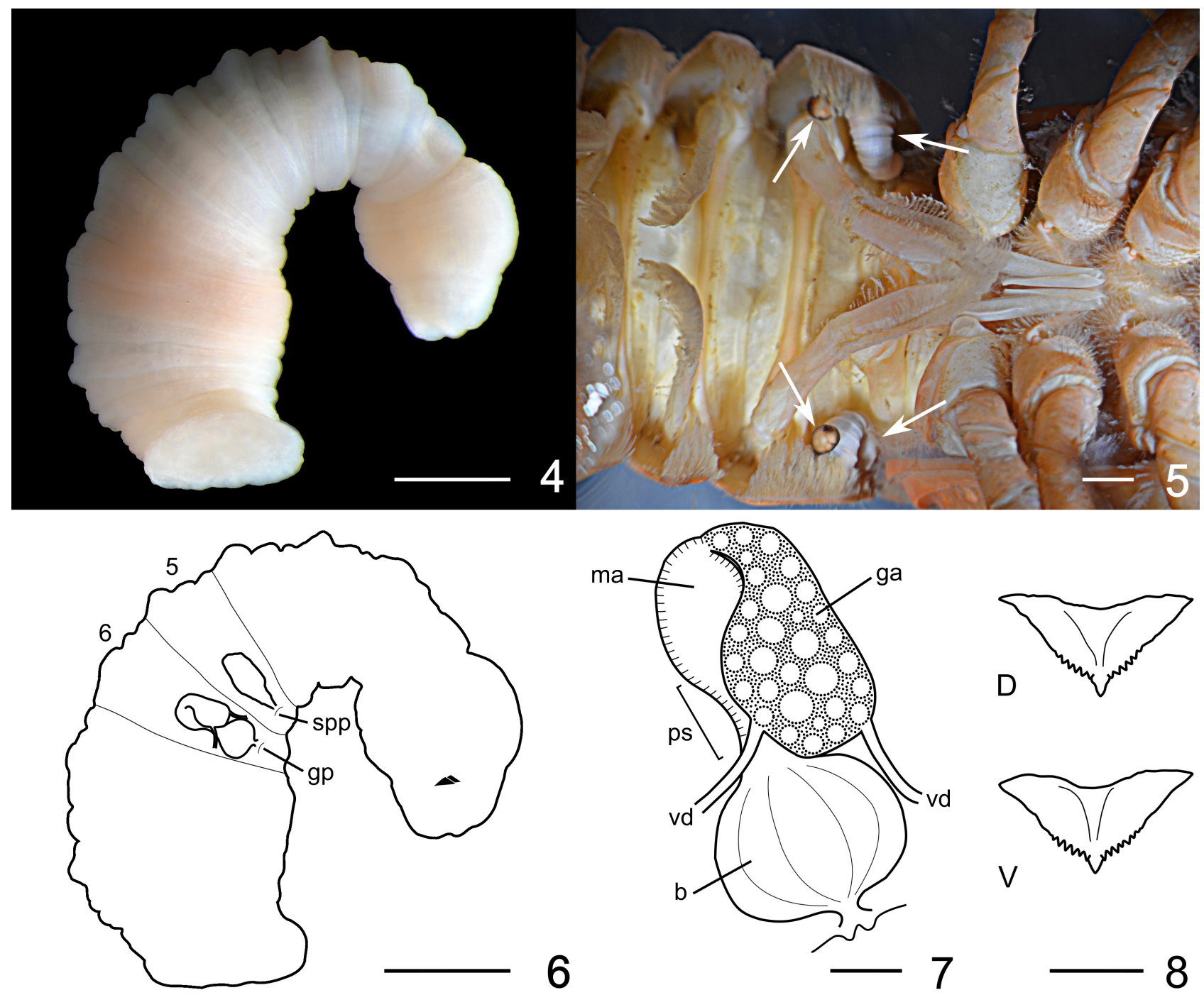
$\mathrm{V}$

FIGURES 4-8. Triannulata magna. Fig. 4. Adult in latero-ventral view (MNHN-HEL656), bar = 1.0mm. Fig. 5. Adults (right arrows) near cocoons (left arrows) on ventral abdomen of Pacifastacus leniusculus, bar $=2.0 \mathrm{~mm}$. Fig. 6. Diagram of an adult in latero-ventral view showing position of jaws, spermatheca in segment 5 and major male organs in segment 6: gp, genital pore, spp, spermatheca pore, bar $=1.0 \mathrm{~mm}$. Fig. 7. Diagram of adult male organs in lateral view: b, bursa; ga, glandular atrium; ma, muscular atrium; ps, penial sheath; vd, vas deferens, bar $=100 \mu \mathrm{m}$. Fig. 8. Juvenile jaws in ventral view with teeth pointing posteriorly: D, dorsal jaw; V, ventral jaw, bar $=50 \mu \mathrm{m}$.

Triannulata magna is endemic on P. leniusculus in the Pacific Northwest, USA, and this is not only the first record of T. magna in Europe, but also in the Palearctic region. Specimens were found in the lateral depressions along the ventral abdominal segments (Fig. 5) and are consistent with its reported ventral body microhabitat. Close to adult T. magna were three cocoons (Fig. 5) with a length, including stalk, of 2.8 to $3.0 \mathrm{~mm}$ and containing 8 to 15 embryos. In one cocoon an embryo was visible and measured about $0.8 \mathrm{~mm}$ long, with a well-formed triangular head, triple body annulations, and triangular jaws with crenelated sides 
and large medium tooth (Fig. 8). These observed morphological characters provide a virtual assurance the cocoons were T. magna. Without seeing such details in an embryo, it could have been possible that other cohabitants, C. gracilis and C. okadai, had deposited their cocoons in the area.

Cambarincola mesochoreus Hoffman, 1963: Adults have a distinct head and a rod-shaped body (Figs 9 and 11), measuring 2.5 to $4.2 \mathrm{~mm}$ long, with two annuli per segment and no transverse segmental ridges. There are four small lobes on the dorsal peristomial lip, which may not always be visible due to preservation effects, and jaws with a dental formula of 5/4 (Fig. 13). The dorsal jaw is triangular with a large median tooth and two pairs of slightly smaller lateral teeth, while the ventral jaw is trapezoidal and has two pairs of teeth that interdigitate with those on the dorsal. Spermatozoa occur in segments 5 and 6 , with the spermatheca located in segment 5 and male organs in 6 (Fig. 11). The male organs consist of a curved glandular atrium (ga) and a longer reflexed prostate gland (Fig. 12, pg). These organs are shown overlaying a muscular atrium and bursa containing a protrusible penis.
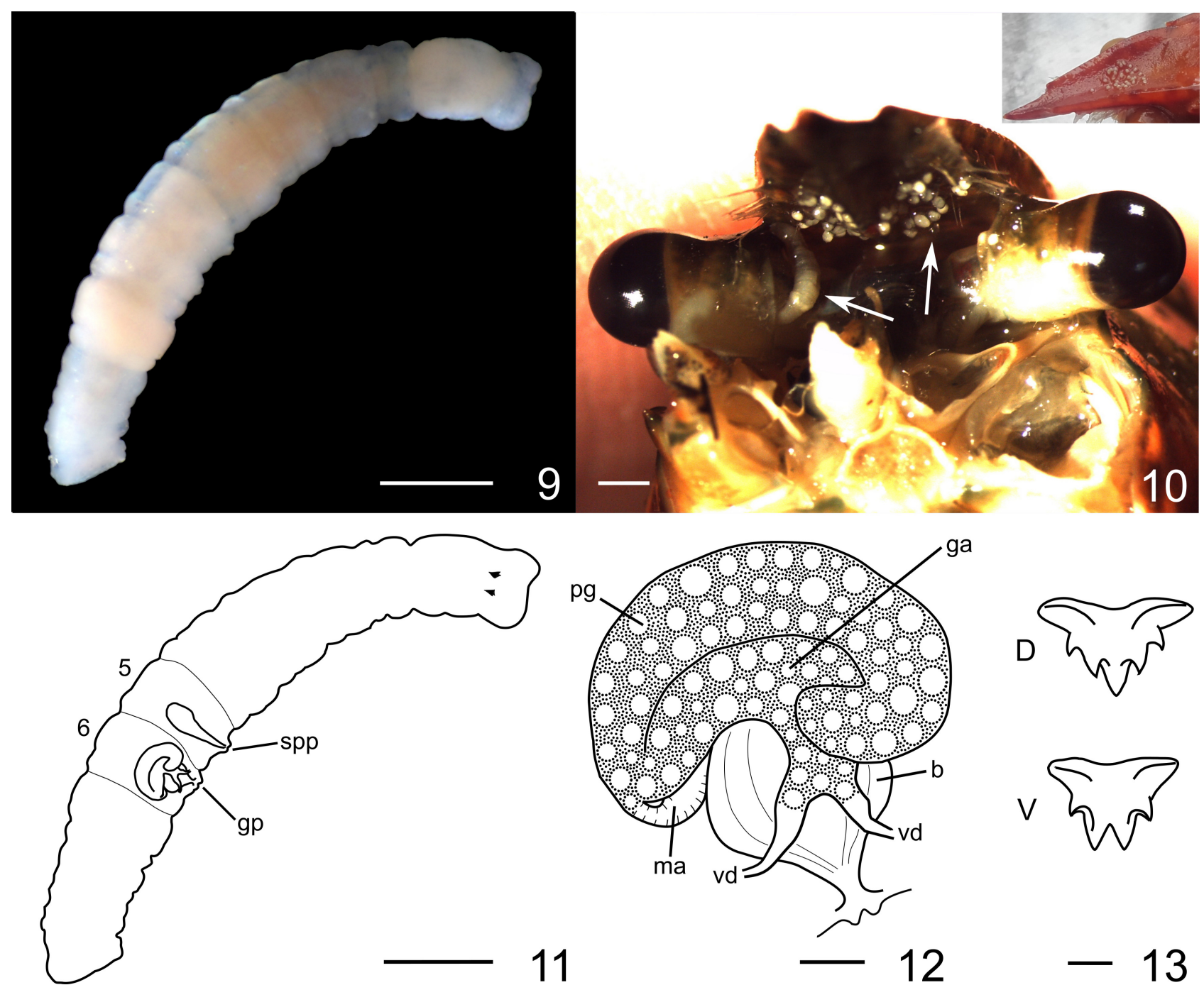

FIGURES 9-13. Cambarincola mesochoreus, for abbreviations see Figs. 4-8. Fig. 9. An adult in lateral view, bar $=0.5 \mathrm{~mm}$. Fig. 10. In foreground, an adult (left arrow) with cocoons (right arrow) under the rostrum of Procambarus clarkii (the antennae and antennules were removed), bar $=1 \mathrm{~mm}$. Thumbnail in top right, cocoons on the rostrum of $P$. clarkii, picture with Julien Rimour used permission. Fig. 11. Diagram of an adult in lateral view showing jaws, spermatheca in segment 5 and major male organs in segment 6 , bar $=0.5 \mathrm{~mm}$. Fig. 12. Diagram of male organs in lateral view: pg, prostate gland, bar $=50 \mu \mathrm{m}$. Fig. 13. Jaws in ventral aspect with teeth pointing posteriorly, bar $=20 \mu \mathrm{m}$.

Cambarincola mesochoreus is endemic on P. clarkii in the southeast USA and adjacent Mexico, and this is the first record of the association in France, although the crayfish are much more widely distributed in the country. Branchiobdellidans were observed over most of the exposed body surface, but the rostrum area 
appeared to be a favored microhabitat for both individuals and cocoons (Fig. 10: arrows and top right thumbnail).

\section{Discussion}

The spread of exotic species and establishment of breeding populations through commercial and accidental translocations is resulting in the reduction or extinction of endemic species and consequent modification or destruction of traditional habitats (Keith \& Allardi 1997; Lévêque 1997). This is particularly noticeable in Europe where large scale commercial introductions of North American crayfishes started about 1960 and have continued to date (Holdich et al. 2009; Kouba et al. 2015). Such translocations of crayfish are always accompanied by their endemic pathogenic and non-pathogenic symbionts (Longshaw 2011). While ectosymbiotic branchiobdellidans are generally non-pathogenic mutualists, a few species have a mainly parasitic association with their host (Gelder \& Williams 2016).

Branchiobdellidans are found in most areas of North America (Gelder 2016) and the majority on crayfish species. However, only a few of these hosts are of commercial interest; Gelder (2004) listed a total of 24 endemic branchiobdellidan species reported on the three most popular commercial crayfishes: P. leniusculus (15), $P$. clarkii (6) and F. limosus (4). Since then, additional exotic crayfishes have been reported in Europe (Kouba et al. 2015), principally $F$. immunis $F$. juvenilis, and Faxonius virilis (Hagen) with at least 10 more ornate species imported by the pet trade (Holdich et al. 2009), some of which also harbor branchiobdellidans. A revision of the endemic branchiobdellidans recorded on the newer crayfish imports has increased the total potential number of North American worms from 24 to about 50 (S.R. Gelder, unpub. data). Some of these are less than $1.5 \mathrm{~mm}$ in length and will only be seen during a careful host examination using a magnification of $\mathrm{x} 20$ or greater. Up to the 1950s, branchiobdellidans found wild in Europe were assuredly members of the Branchiobdella, but as largescale translocations of exotic North American crayfishes started, their endemic branchiobdellidans began to be observed on the continent (Franzén 1962). Identification of these exotic branchiobdellidans presented researchers with a challenge as some species had not been described at the time of their collection. For example, Franzén (1962) used the name of an eastern North American species, but he actually studied X. victoriensis which was only described 28 years later by Gelder and Hall (1990). Although being aware of this background, some reviewers still cite the original name, and this perpetuates the confusion in the literature. The taxonomic situation of North America branchiobdellidans has greatly improved with the availability of a recently published key to Nearctic species (Gelder 2016). Brief descriptions of the commonly occurring exotic European branchiobdellidans were included here for C. mesochoreus and T. magna, and in Gelder et al. (2012), to assist in the accurate identification and recognition of these species as their ranges expand.

During this freshwater faunal survey, four species of crayfish - P. leniusculus, F. limosus, P. clarkii and A. pallipes - were found carrying North American branchiobdellidans at 105 sites in France. Pacifastacus leniusculus tends to be found in colder, upper and headwaters of the Massif Central, Plateau de Millevaches, Massif Morvan, Basse Normandie and near Saint-Michel in northeast France. The three sites near SaintMichel in northeast France are quite close together and each contains a multiple species cohabitation but with differing compositions: site $93-C$. okadai and X. victoriensis, site $94-C$. gracilis, C. okadai and $X$. victoriensis, and site $95-$ - . gracilis, C. okadai, T. magna and X. victoriensis. In addition, sites 93 and 95 were sampled twice and the same species composition was found. Site 95 is unique as it is the first exotic, quadruple cohabitation of branchiobdellidans on P. leniusculus to be found in Europe, and also contains the first record of T. magna in the Palaearctic realm. It is probable that P. leniusculus and its four branchiobdellidan species were introduced to these sites at the same time, but why one and two species were lost at sites 93 and 94 respectively, is unknown. Similarly, the disparate distribution of triple species cohabitations at sites $7,11,13,46,48,49,63,64$, and 88 , with two or single species at nearby sites is most likely the result of the same combination of unknown factors. One approach that might explain these variations in worm species on P. leniusculus is to trace the host's original locations back in the Pacific Northwest, USA. Unfortunately, the endemic distribution of P. leniusculus is complex and not fully understood (Larson and Williams 2016) and this is compounded as wild crayfish were collected from a number of waterbodies and held for subsequent translocation, thus resulting in both a taxonomic and geographic mixing. Finally, after the initial translocation into Europe, many secondary introductions, both legal and illegal occurred, not only from the USA but also from breeding stocks in Europe. An attempt at 
tracking these movements in Europe was attempted using fragments of the mitochondrial gene for cytochrome $c$ oxidase subunit I (COI) by Petrusek et al. (2017), but no clear distribution of haplotypes was found that corresponded to the various introductions. Therefore, any possibility of tracing the observed branchiobdellidan species combinations found in this study to their origins in the Pacific Northwest USA was discounted.

Following P. clarkii's Spanish introduction in 1973 from Louisiana, USA, it has spread across the Iberian Peninsula, while subsequent introductions of P. leniusculus onto the Peninsula tended to extend across the northern half of the region (Kouba et al. 2015). Xironogiton victoriensis on P. leniusculus was first reported in the Basque Country (Gelder 1999) and later in the Ebro Basin, northeastern Spain, by Oscoz et al. (2010). Although the two crayfish species typically live in different habitats, both have shown an adaptability which has allowed them to cohabit in certain areas. Vedia et al. (2014) reported such an area in the River Piedra, Zaragoza, Spain, where X. victoriensis were found on both crayfishes. Iván Vedia (pers. comm.) also observed that this branchiobdellidan occupied the same microhabitat on the chelae on the adopted $P$. clarkii. This find is consistent with our observation on the exotic F. limosus and the endemic A. pallipes and that of the first published record of such an association on this last crayfish recently described in Teruel, eastern Spain, by Martín-Torrijos et al. (2018).

It is most likely that some illegal introductions $P$. clarkii into France came from Spain (Holdich et al. 2009; Kouba et al. 2015) and were probably supplemented by translocations from Louisiana, USA. Our study indicates P. clarkii are predominantly found in southern and southwestern France, with scattered records across the rest of the country (Kouba et al. 2015), but only at site 1 in the Adour drainages was it found to carry C. mesochoreus (Table 1). Subsequent collections in the same southwest area have shown this is not an isolated occurrence (J.-F. Parpet, unpub obs.). Although this crayfish has an almost worldwide distribution (Kouba et al. 2015), endemic branchiobdellidans on translocated stocks are surprisingly rare with the only other European record being in northern Italy (Gelder et al. 1994), and a recent one in Japan (Ohtaka et al. 2017). A subsequent study of the northern Italian population of P. clarkii (Gelder at al. 1999) found the association unchanged, but in a second population a short distance away, the $C$. mesochoreus population had been replaced by European Branchiobdella italica Canegallo and B. parasita. Unfortunately, events leading to this replacement were not observed, but it became the first report of Branchiobdella species adopting $P$. clarkii. Although $C$. mesochoreus is the most common species found on P. clarkii, it is not the only one, and so specimens need to be carefully examined for sympatric Cambarincola barbarae Holt and Cambarincola pamelae Holt. All three species have similar body shapes and a dental formula of $5 / 4$, but each has differing shaped jaws which can be only recognized if the specimens are correctly orientated on a microscope slide. Hence an examination should also include the male reproductive system to confirm the species identification and determine if a multi-species cohabitation has been found (Holt \& Opell 1993).

The first European introduction of $F$. limosus from the USA was made into Poland in 1890, followed by an unsuccessful attempt into northern France in 1896. A subsequent translocation of stock from Germany to France resulted in a breeding population being established shortly after (Kouba et al. 2015). To date, none of its endemic branchiobdellidans have been found on F. limosus in Europe, even though it was the second most numerous species to be collected in our survey. Twenty-one sites were found with $F$. limosus and $P$. leniusculus cohabiting, while at four of these sites (24,55 and 100), X. victoriensis only populated $P$. leniusculus, in contrast with site 43, where only F. limosus carried X. victoriensis. This observation of $X$. victoriensis transferring to another host species could be explained if the P. leniusculus was unhealthy or molting. Unfortunately, no record of its condition was made, but whatever the reason, this is the first record of the western North American X. victoriensis being found on an exotic eastern F. limosus. This crayfish's acceptability also extends to endemic Branchiobdella species when it cohabits waters with European crayfishes (Bláha et al. 2017; Duriš et al. 2006; Dr. W. Struzynski, unpub. obs.; Vogt 1999). The reverse is also true as X. victoriensis has adopted the European A. pallipes at two closely located sites (56 and 57) making it the first report of such an ectosymbiotic combination in France and follows that in Spain (MartinTorrijos et al. 2018). This association appears to be stable, as it was observed in samples taken at the sites two years apart. Although no exotic crayfishes were captured at sites 56 and 57, at site 55 in an adjacent tributary, F. limosus and P. leniusculus were found, with X. victoriensis on the latter species. Whether this reflected a host preference is difficult to say. However, it should be remembered that crayfish can travel overland from one freshwater sources to another, e.g., ponds, streams, seeps, and as demonstrated experimentally (Hunt et al. 2018) are capable of carrying viable branchiobdellidans with them. 
These observations demonstrate conclusively that most branchiobdellidans are not species specific to a particular crayfish host, or even to one from its endemic region. Therefore, endemic associations once restricted to a region can no longer be assumed, as uncontrolled and new crayfish translocations continue to occur. The usual method of branchiobdellidan transfer from one host to another is during direct contact (Hunt et al. 2018). Alternatively, branchiobdellidans will leave the host following molting, bodily damage and death, to live on the substratum until another crayfish comes in contact with them, whether endemic or acceptable exotic. Such a temporary free-living situation was reported at sites 2, 12 and 59, where $X$. victoriensis was found in substrate samples, but no crayfish were captured. It is most probable crayfish were present, but they eluded capture during the collection period. Although free-living branchiobdellidans have been recorded in similar situations (Holt 1973; Timm 1991) and experimentally by Hunt et al (2018), other extensive examinations of substrate samples have not found these worms (James et al. 2017, Gelder unpub. data). As the majority of branchiobdellidans have a diet of micro-flora and -fauna, food would not be a limiting factor while waiting for a host to make contact with them. Indeed in vitro observations of some branchiobdellidan species have shown they can be maintained alive for months (Gelder and Williams, 2015). However, it is most likely survival time is both species and conditions dependent. James et al. (2017) observed that $X$. victoriensis survived for over 21 weeks and $C$. okadai for less than two weeks while cohabiting on P. leniusculus, but when kept separately in vitro without a host, both ectosymbionts lasted for about the same amount of time (14 weeks). This free-living period would be adequate under most conditions for them to survive while awaiting contact with a new host. Such habitat adaptability and capacity to adopt either local endemic or exotic astacoidean crayfish favors the survival and range expansion of branchiobdellidans in Europe.

A consideration not so far discussed is the potential for branchiobdellidans in Europe to adopt commercially imported Australian crayfish. Yabbys, or Cherax destructor Clark were imported into Spain in 1983 from a farm in California, USA, and Redclaws, Cherax quadricarinatus (von Martens), primarily into Italy (Kouba et al. 2015). Although Australian crayfishes do not have endemic branchiobdellidans, they do carry flatworm temnocephalidans which fill the same niche (Gelder 1999). This ectosymbiotic association has already been reported three times in Europe, with Temnosewellia minor Haswell (synonym Temnocephala minor) on C. destructor in Italy (Quaglio et al. 1999; Scalici et al. 2009; Chiesa et al. 2015), but it is unlikely that these are the only examples of the association in Europe. Whether endemic or exotic branchiobdellidans are capable of adopting the southern parastacoidean crayfish is not known at this time. However, Vayssière (1898) did find branchiobdellidans and temnocephalidans cohabiting a specimen of Procambarus digueti Bouvier in Mexico. This demonstrates that Temnocephala sp. have found a northern cambarid crayfish an acceptable host, therefore it is predicted that branchiobdellidans may well adopt Cherax species if the opportunity arises.

The demand for crayfish is being driven by increased human consumption and the pet trade, and as a result the business of illegally translocating crayfishes is thriving. Pacifastacus leniusculus and P. clarkii have been known in Britain since 1970 (Holdich \& Lowery 1988) and extensive studies have followed (Holdich et al. 2014); therefore, if exotic branchiobdellidans were present they would have been reported. As the first report of P. leniusculus carrying both $C$. okadai and X. victoriensis only occurred recently in south Wales (James et al. 2015), the population must have been a very recent translocation from outside the UK. This assessment is further supported as extensive sampling of Welsh rivers over the previous 35 years have yielded no branchiobdellidans (James et al. 2017). One explanation for these south Wales populations of infected $P$. leniusculus is that specimens were acquired for gastronomic reasons, probably from France, and then some individuals were either released or escaped into local waterbodies to form a starter population. This hypothesis is certainly supported by our reported presence of $C$. okadai and X. victoriensis on P. leniusculus in numerous areas of France. In response to the public demand in France, particularly at holiday times, fish markets offer both endemic and exotic live crayfish under the label "European crayfish" (J.-F. Parpet, unpub. obs.). Technically this would be true if the exotic species were raised in Europe, and so the chances they were imported into the country are high. However, a recent decree bans the import, transport, sale and purchase of live specimens of F. limosus, P. leniusculus and P. clarkii in metropolitan France (decree of February 14, 2018).

Although most European countries have stringent legislation banning uncontrolled importation and transportation of exotic crayfish species for human consumption and the pet trade, public demand appears to be greater than current enforcement efforts. In areas not yet invaded by the exotic crayfishes, active 
enforcement of regulations has a chance to stop further range expansions. However, such measures need to be accompanied by a coordinated public education program on the environmental damage and financial costs these invasives cause to recreational areas and natural resources. Exotic crayfishes continue to be introduced for commercial reasons, but the hidden costs resulting from such biological invasions, e.g., the ancillary introduction of "crayfish plague", have resulted in much higher indirect damages than is generally recognized.

\section{Acknowledgement}

Our thanks to the collection teams in all Asconit Consultant Agencies in France, and to Prof. Jean-Loup Justine for accepting specimens of the five exotic branchiobdellidan species for deposition in the National Collection, MNHN, Paris, France. We also thank Dr. Ivan Vedia (Colegio Miravalles-El Redín, Pampelune, Spain), for sharing his observations on P. clarkii, Raphael Krieg (Koordinationsstelle Flusskrebse Schweiz, Muttenz, Switzerland) for sending us exotic branchiobdellidan specimens, Dr. David Templeman and Ton Van Haaren (Eurofins Omegam, Amsterdam, Netherland) for reporting X. victoriensis in Luxembourg, and JeanPierre Faure (FDRMLPPMA, La-Tour-de-Salvigny, France) for observations of X. victoriensis on A. pallipes. We also wish to acknowledge the help and permission to publish survey results from Jean-Pierre Rebillard (Water Agency Adour-Garonne), Jacky Durocher (Water Agency Loire-Bretagne) and Aline Cattan and Estelle Dallery (Water Agency Seine-Normandie) and Dr. Nicolas Poulet (AFB, Toulouse) France. In addition, our appreciation to Dr. Andrea M. Gorman (University of Maine at Presque Isle, USA), and to the reviewers, Dr. Tarmo Timm and Professor Mitko A. Subchev, for their constructive suggestions on the manuscript.

\section{References}

Ames, C.W., Helms, B.S. \& Stoeckel, J.A. (2015) Habitat mediates the outcome of a cleaning symbiosis for a facultatively burrowing crayfish. Freshwater Biology, 60, 989-999. https://doi.org/10.1111/fwb.12559

Bláha, M., Ložek, F., Buřič, M., Kouba, A. \& Kozák, P. (2017) Native European branchiobdellids on non-native crayfishes: Report from the Czech Republic. Journal of Limnology, 77 (1), 164-168. https://doi.org/10.4081/jlimnol.2017.1679

Chiesa, S., Scalici, M., Lucentini, L. \& Nonnis Marzano, F. (2015) Molecular identification of an alien temnocephalan crayfish parasite in Italian freshwaters. Aquatic Invasions, 10, 209-216. https://doi.org/10.3391/ai.2015.10.2.09

Dražina, T., Korša, A., Špoljar, M., Maguire, I. \& Klobučar, G.I.V. (2018) Epifauna of native and alien freshwater crayfish species (Crustacea: Decapoda): a host-specific community? Freshwater Science, 37 (3), 593-604. http://dx.doi.org//10.1086/698764

Duriš, Z., Horká, I., Kristian, J. \& Kozák, P. (2006) Some case of Macro-Epibiosis on the invasive crayfish Faxonius limosus in the Czech Republic. Bulletin Français de la Pêche et de la Pisciculture, 380/381, 1325-1337. https://doi.org/10.1051/kmae:2006038

Franzén, Å. (1962) Notes on the morphology and histology of Xironogiton instabilia (Moore, 1893) (Fam. Branchiobdellidae) with special reference to the muscle cells. Zoologiska Bidrag från Uppsala, 35, 369-383.

Gelder, S.R. (1999) Zoogeography of branchiobdellidans (Annelida) and temnocephalidans (Platyhelminthes) ectosymbiotic on freshwater crustaceans, and their reactions to one another in vitro. Hydrobiologia, 406, 21-31. https://doi.org/10.1023/A:1003755630718

Gelder, S.R. (2004) Endemic ectosymbiotic branchiobdellidans (Annelida: Clitellata) reported on three "export" species of North American crayfish (Crustacea: Astacoidea). Freshwater Crayfish, 14, 221-227.

Gelder, S.R. (2016) Clitellata: Branchiobdellida. In: Thorp, J. \& Rogers, D.C. (Eds.), Keys to Nearctic Fauna: Thorp and Covich's Freshwater Invertebrates, Volume II. Academic Press, pp. 234-244.

Gelder, S.R., Delmastro, G.B. \& Ferraguti, M. (1994) A report on branchiobdellidans (Annelida: Clitellata) and a taxonomic key to the species in northern Italy, including the first record of Cambarincola mesochoreus on the introduced American red swamp crayfish. Bolletino di zoologia, 61, 179-183.

https://doi.org/10.1080/11250009409355880

Gelder, S.R., Delmastro, G.B. \& Rayburn, J.N. (1999) Distribution of native and exotic branchiobdellidans (Annelida: 
Clitellata) on their respective crayfish hosts in northern Italy, with the first record of native Branchiobdella species on an exotic North American crayfish. Journal of Limnology, 58, 20-24.

https://doi.org/10.4081/jlimnol.1999.20

Gelder, S.R. \& Hall, L.A. (1990) Description of Xironogiton victoriensis n.sp. from British Columbia, Canada, with remarks on other species and a Wagner analysis of Xironogiton (Clitellata: Branchiobdellida). Canadian Journal of Zoology, 68, 2352-2359.

https://doi.org/10.1139/z90-326

Gelder, S.R., Parpet, J.-F. \& Quaglio, F. (2012) First report of two North American branchiobdellidans (Annelida: Clitellata) or crayfish worms on signal crayfish in Europe with a discussion of similar introductions into Japan. Annales de Limnologie. International Journal of Limnology, 48, 315-322. https://doi.org/10.1051/limn/2012021

Gelder, S.R. \& Williams, B.W. (2015) Clitellata: Branchiobdellida. In: Thorp, J. \& Rogers, D.C. (Eds.), Ecology and General Biology: Thorp and Covich's Freshwater Invertebrates, Volume I. Academic Press, 551-563. https://doi.org/10.1016/B978-0-12-385026-3.00022-X

Gelder, S.R. \& Williams, B.W. (2016) Global Overview of Branchiobdellida (Annelida: Clitellata). In: Kawai, T., Faulkes, Z. \& Scholtz, G. (Eds.), Freshwater Crayfish: A Global Overview. CRC Press, New York, 628-654. https://doi.org/10.1201/b18723-27

Holdich, D.M., James, J., Jackson, C. \& Peay, S. (2014) The North American signal crayfish, with particular reference to its success as an invasive species in Great Britain, Ethology, Ecology \& Evolution, 26 (2-3), 232-262. https://doi.org/10.1080/03949370.2014.903380

Holdich, D.M. \& Lowery, R.S. (1988) Freshwater Crayfish. Biology, Management and Conservation. Croom Helm (Chapman $\&$ Hall), London, 497pp.

Holdich, D.M., Reynolds, J.D., Souty-Grosset, C. \& Silby, P.J. (2009) A review of the ever increasing threat to European crayfish from non-indigenous crayfish species. Knowledge and Management of Aquatic Ecosystems, 394-395, 11, 1-46. https://doi.org/10.1051/kmae/2009025

Holt, P.C. (1973) A free-living branchiobdellid (Annelida: Clitellata)? Transactions of the American Microscopical Society, 92 , $152-153$. https://doi.org/10.2307/3225182

Holt, P.C. (1974) An emendation of the genus Triannulata with the assignment of Triannulata montana to Cambarincola Ellis 1912 (Clitellata Branchiobdellida). Proceedings of the Biological Society of Washington, 87, 57-72.

Holt, P.C. \& Opell, B.D. (1993) A checklist of and illustrated key to the genera and species of the Central and North American Cambarincolidae (Clitellata: Branchiobdellida). Proceedings of the Biological Society of Washington, 106, 251-295.

Hunt, R., Rhidian, J., James, J. \& Cable, J. (2018) Transmission and terrestrial dispersal of non-native ectosymbionts on invasive crayfish. Hydrobiologia, 820, 135-144. https://doi.org/10.1007/s10750-018-3647-3

James, J., Cable, J., Richardson, G. ,Davidson, K.E. \& Mackie, A.S.Y. (2015) Two alien species of Branchiobdellida (Annelida: Clitellata) new to the British Isles: a morphological and molecular study. Aquatic Invasions, 10, 371-383. https://doi.org/10.3391/ai.2015.10.4.02

James, J., Davidson, K.E., Hunt, R. \& Cable, J. (2017) Assessing the invasion potential of non-native branchiobdellidans: experimental studies of survival, reproduction and competition. Knowledge and Management of Aquatic Ecosystems, 418, $35-43$. https://doi.org/10.1051/kmae/2017030

Keith, P. \& Allardi, J. (1997) Bilan des introductions de poissons d'eau douce en France. Knowledge and Management of Aquatic Ecosystems, 344-345, 181-191. https://doi.org/10.1051/kmae:1997021

Kirjavainen, J. \& Westman, K. (1999) Natural history and development of the introduced signal crayfish Pacifastacus leniusculus, in a small, isolated Finnish lake, from 1968 to 1993. Aquatic Living Resources, 12, 387-401. https://doi.org/10.1016/S0990-7440(99)00110-2

Kouba, A., Buřič, M. \& Petrusek, A. (2015) Crayfish species in Europe. In: Kozák, P., Ďuriš, Z., Petrusek, A., Buřič, M., Horká, I., Kouba, A., Kozubíková-Balcarová, E. \& Policar, T. (Eds.), Crayfish biology and culture. University of South Bohemia in České Budějovice, Faculty of Fisheries and Protection of Waters, Vodňany, Czech Republic, pp. 81-163.

Kouba, A., Petrusek, A. \& Kozák, P. (2014) Continental-wide distribution of crayfish species in Europe: Update and maps. Knowledge and Management of Aquatic Ecosystems, 413, 1-31. https://doi.org/10.1051/kmae/2014007

Kovács, T. \& Juhász, P. (2007) Data to the distribution of crayfish worms (Branchiobdellidae) in Hungary. Folia HistoricoNaturalia Musei Matraensis, 31, 77-79. 
Kozák, P., Policar, T., Buřič, M. \& Kouba, A. (2015) Monitoring of crayfish appearance. In: Kozák, P., Ďuriš, Z., Petrusek, A., Buřič, M., Horká, I., Kouba, A., Kozubíková-Balcarová, E. \& Policar, T. (Eds.), Crayfish biology and culture. University of South Bohemia in České Budějovice, Faculty of Fisheries and Protection of Waters, Vodňany, Czech Republic, pp. 367391.

Larson, E.R. \& Williams, B.W. (2016) Historical biogeography of Pacifastacus crayfishes and their branchiobdellian and entocytherid ectosymbionts in western North America. In: Kawai, T., Faulkes, Z. \& Scholtz, G. (Eds.), Freshwater Crayfish: A Global Overview. Boca Raton, CRC Press, 404-447. https://doi.org/10.1201/b18723-21

Laurent, P.J. (2007) A French population of Pacifastacus leniusculus bears the North American parasite branchiobdellidan ectosymbiont Xironogiton victoriensis. Crayfish News: IAA News letter, 29, 5-6.

Lecaplain, B. \& Noël, F. (2015) Branchiobdellidées et Hirudinées du Nord-Ouest de la France, 24 pp. Available from: https:// inpn.mnhn.fr/docs/inventaires/LECAPLAIN,NOEL-manuel_hirudin\%c3\%a9s_NOFrance_V2_Juillet2015.pdf (accessed 25 January 2017)

Lévêque, C. (1997) Introductions de nouvelles espèces de poissons dans les eaux douces tropicales: objectifs et conséquences. Knowledge and Management of Aquatic Ecosystems, 344-345, 9-91. https://doi.org/10.1051/kmae:1997012

Longshaw, M. (2011) Diseases of crayfish: A review. Journal of Invertebrate Pathology, 106, 54-70. https://doi.org/10.1016/j.jip.2010.09.013

Martens, A., Grabow, K., Rapp, S. \& Schoolmann, G. (2006) Der Krebsegel Xironogiton victoriensis wurde mit dem Signalkrebs Pacifastacus leniusculus auch nach Deutschland eingeschleppt (Annelida: Branchiobdellida; Crustacea: Astacidae). Lauterbornia, 58, 147-145.

Martín-Torrijos, L., Gelder, S.R. \& Diéguez-Uribeondo, J. (2018) A new kid in town: First case of an alien worm, Xironogiton victoriensis (Annelida: Clitellata) on a native European freshwater crayfish. Aquaculture, 496, 39-42. https://doi.org/10.1016/j.aquaculture.2018.06.086

Nesemann, H. \& Neubert, E. (1999) Süßwasserfauna von Mitteleuropa. Bd. 6 Annelida. 2. Clitellata: Branchiobdellida, Acanthobdellea, Hirudinea. Spectrum Akademischer Verlag GmbH, Heidelberg, Berlin, 192 pp.

Odier, A. (1823) Mémoire sur le Branchiobdelle, nouveau genre d'Annélides de la famille des Hirudinées. Mémoires de la Société d'histoire naturelle de Paris, 1, 69-78.

Ohtaka, A., Gelder, S.R. \& Smith, R.J. (2017) Long-anticipated new records of an ectosymbiotic branchiobdellidan and an ostracod on the North American red swamp crayfish, Procambarus clarkii (Girard, 1852) from an urban stream in Tokyo, Japan. Plankton \& Benthos Research, 12, 123-128. https://doi.org/10.3800/pbr.12.123

Oscoz, J., Tomás, P. \& Durán, C. (2010) Review and new records of non-indigenous freshwater invertebrates in the Ebro River basin (Northeast Spain). Aquatic Invasions, 5, 263-284. https://doi.org/10.3391/ai.2010.5.3.04

Petrusek, A., Filipová, L., Kozubíková-Balcarová, E. \& Grandjean, F. (2017) High genetic variation of invasive signal crayfish in Europe reflects multiple introductions and secondary translocations. Freshwater Science, 36, 838-850. https://doi.org/10.1086/694866

Quaglio, F., Fioravanti, M.L., Gelder, S.R., Giannetto, S., Trentini, M., Nobile, L, Maxia, M. \& Morolli, C. (2002) Infestation of the branchiobdellidan, Xironogiton victoriensis (Annelida, Clitellata), on the signal crayfish (Pacifastacus leniusculus) from Auenbachl Creek, Alto Adige/Süd Tyrol, Italy. Freshwater Crayfish, 13, 274-279.

Quaglio, F., Trentini, M., Mazzoni, D. \& Nobile, L. (1999) Observations on Temnocephalid (Platyhelminthes) ectosymbionts in Australian freshwater crayfish (Cherax destructor Clark) introduced in Italy. Freshwater Crayfish, 12, 335-342

Scalici, M., Chiesa, S., Gherardi, F., Ruffini, M., Gibertini, G. \& Nonnis Marzano, F. (2009) The new threat to Italian inland waters from the alien crayfish "gang": the Australian Cherax destructor Clark, 1936. Hydrobiologia, 632, 341-345. https://doi.org/10.1007/s10750-009-9839-0

Skelton, J., Farrell, K.J., Creed, R.P., Williams, B.W., Ames, C., Helms, B.S., Stoekel, J. \& Brown, B.L. (2013) Servants, scoundrels, and hitchhikers: current understanding of the complex interactions between crayfish and their ectosymbiotic worms (Branchiobdellida). Freshwater Science, 32 (4), 1345-1357. https://doi.org/10.1899/12-198.1

Subchev, M.A. (2008) Branchiobdellidans (Annelida: Clitellata) found in the crayfish and annelid collections of the French National Museum of Natural History (Paris), and on recently collected crayfishes from France. Acta zoologica Bulgarica, 60, 233-237.

Subchev, M.A. (2014) The genus Branchiobdella Odier, 1823 (Annelida, Clitellata, Branchiobdellida): A review of its European Species. Acta Zoologica Bulgarica, 66 (1), 5-20.

Subchev, M.A. (2016) First report of Branchiobdella Odier, 1923 from Belgium. Acta Zoologica Bulgarica, 68 (1), $141-143$. 
Timm, T. (1991) Branchiobdellida (Oligochaeta) from the farthest South-East of the U.S.S.R. Zoologica Scripta, 20, $321-331$. https://doi.org/10.1111/j.1463-6409.1991.tb00297.x

Vayssière, A. (1898) Description du Temnocephala mexicana, nov. sp. Annales de la Faculté des Sciences de Marseille, 8, 227235.

Vedia, I., Oscoz, J., Rueda, J., Miranda, R., García-Roger, E.M., Baquero, E. \& Gelder, S.R. (2014) An alien ectosymbiotic branchiobdellidan (Annelida: Clitellata) adopting exotic crayfish: a biological co-invasion with unpredictable consequences. Inland Waters, 5, 89-92.

https://doi.org/10.5268/IW-5.1.799

Vogt, G. (1999) Disease of European freshwater crayfish, with particular emphasis on interspecific transmission of pathogens. In: Gherardi, F. \& Holdich, D.M. (Eds.), Crayfish in Europea as alien species. How to make the best of a bad situation? A.A. Balkema, Brookfield, pp. 87-103.

https://doi.org/10.1201/9781315140469-7 